\title{
Kant's Studies in Ukrainian Philosophy of Soviet Period
}

\author{
Vadym Tytarenko \\ $\mathrm{PhD}$, Assistant Professor, Taras Shevchenko National University of Kyiv \\ (Kyiv, Ukraine) \\ E-mail: tytarenko.vadym@gmail.com \\ ORCID: 0000-0001-9251-8859
}

\section{Sergii Rudenko}

\author{
Doctor of Philosophical Sciences, Associate Professor, \\ Taras Shevchenko National University of Kyiv \\ (Kyiv, Ukraine) \\ E-mail: rudenkosrg@gmail.com \\ ORCID: 0000-0001-9069-0989
}

This writing is devoted to the brief review of Immanuel Kant's philosophy studies and receptions of his philosophical concepts within the Ukrainian philosophy of Soviet period. Such attempt is actually pertinent because nowadays we definitely need to reconsider the soviet philosophical heritage for better understanding the real value of any philosophical conclusions and worldview-concerning statements which were made in the times of soviet ideology hegemony. Additionally, mentioned reconsidering is presently urgent because Ukrainian intellectual culture is now looking for its identity and is trying to identify the stillremaining ideological totalitarian elements which spoil the originality and objectiveness of its products.

The present review attempts to identify which totalitarian intentions and prejudices were used to interpret and evaluate the Immanuel Kant's heritage in the texts written by several selected Ukrainian philosophers of the Soviet period. Nevertheless, it's obvious that absolutely impossible to avoid talking about Georg Wilhelm Friedrich Hegel's philosophical position interpretation by the same authors. Kant's and Hegel's soviet-Ukrainian interpretations were often connected, because there was a general trend of soviet Marxist history of philosophy to interpret Kant as the "worse" version of Hegel.

To fulfill the general image of Kant's philosophy interpretation in Ukrainian philosophy and its future perspectives, this paper also delivers some common information about the whole historical path of Kant's interpretations and receptions.

Keywords: history of philosophy, Ukrainian philosophy, Soviet philosophy, German classical idealism, Immanuel Kant, totalitarianism, culture.

Received January 25, 2018; accepted March 9, 2018

Future Human Image, Volume 9, 2018 :

DOI: $10.29202 /$ fhi/9/11
(C) Tytarenko, Vadym, 2018
(C) Rudenko, Sergii, 2018 


\section{Introduction}

The philosophical heritage of Immanuel Kant is a significant element of the intellectual history of mankind. Nowadays, of course, it's impossible to do philosophy in the same way as Kant did it. Nevertheless, it's in the same time, impossible to do philosophy without taking into the consideration his contribution.

Morden Ukrainian philosophy needs a fundamental reconsideration of the Kant's philosophical heritage because of the numerous totalitarian prejudices which are still exist within the cultural practices of the contemporary society. The aim of this writing is to make a brief review of the history of Kant's studies in Ukraine, focusing on the peculiarities of the soviet totalitarian interpretations of the historical role and meaning of Kant's philosophy.

This review is the starting point of the future more fundamental research on the totalitarian prejudices which are still present in Ukrainian philosophical culture.

The "System of Critical Idealism" created by Immanuel Kant influenced a great variety of different philosophical inquiries all over the world. Kant's philosophy studies in Ukraine starts in $19^{\text {th }}$ century and can be divided into three main periods:1) early receptions and interpretations (19 $9^{\text {th }}$ century); 2) soviet interpretation; 3) present interpretations (since 1991). In authors opinion it is necessary to outline the peculiarities of each period.

Immanuel Kant's philosophy was not so popular in Ukraine in $19^{\text {th }}$ century as, for example, the philosophical heritage of Friedrich Josef Shelling. Nevertheless its appearance in Ukrainian scientific and philosophical discourse was a significant step of development of philosophical and scientific culture.

Ukrainian philosophers and scientists of $19^{\text {th }}$ century who were interested in Kant's philosophy, mostly became a transmitters of a specific rational, transcendental type of worldview that influenced their scientific research. Most of them were professors in different Ukrainian universities (Lviv, Kharkiv, Kyiv and so forth.) The main Ukrainian Kant's philosophy influenced thinkers of that time were:

Petro Lodij (1764-1829) was a Ukrainian philosopher, pedagogue, jurist. His academic career started at Lviv university (at present time it is Ivan Franko National University of Lviv). Since 1787 to 1802 he was on the position of professor of theoretical and practical philosophy. After the Ukrainian language subject teaching was prohibited by Austrian government, he moved to Kakow, where worked as the professor of mathematics and philosophy (1802-1803) in Krakow university (at present time The Jagiellonian University). Since 1803-1821 Petro Lodij worked as the professor of philosophy in St. Petersburg University (Russia). His main philosophical works were based and on Kant's critical methodology.

Jacob Ruban (1760-1806) was acclaimed for his achievements in mathematics, history and translations. Being a professor of Black sea navigation school in Mykolaiv, he published the first Russian translation (1803) of Kant's "Groundwork of the Metaphysics of Morals".

Ludwig Jacob (1759-1827) was a German philosopher and economist. He had changed several teaching and administrative positions in The University of Halle (presently Martin Luther University of Halle-Wittenberg) by the time he arrived to Kharkiv to take a professor position in local University. During teaching in Kharkiv University (1807-1809), professor Jacob widely contributed in general and special acquaintance of Ukrainian students to the crucial critical ideas which were propounded by Emanuel Kant. But for his interpretative and enlightening activity local students became more confident in philosophical trends of that time. 
Georgii Chelpanov (1862-1936) was doing psychology and philosophy, working on the professor position in Kyiv University. Teaching Philosophy, Psychology and Logic, professor Chelpanov was sure that the theory of cognition by Emanuel Kant is a perfect basis of psychology. His lectures widely touched upon the crucial points of Kant's epistemology and the possible ways of its practical implementation. As a logician, he proclaimed that the ground basis of logic lies within an a priori forms of reasoning. Nevertheless, he never followed the theories of total dependence of the Universe existence on human being's rational and cognitional abilities. The intellectual and philosophical environment of Ukraine in 19th century and German classical philosophy reception within its limits are well described and researched in the monograph by the modern Ukrainian historian of philosophy Sergii Rudenko [Rudenko, 2008].

\section{Soviet transformations in the History of Philosophy}

The soviet ideology expansion over Ukrainian intellectual culture caused fundamental changes in the topics and the way of providing of philosophical inquires and research within all subfields of philosophy. The variety of topics and methods of philosophical research was reduced to Marxist-linked topics and Marxist-Leninist dialectics. Aim and scope of any philosophical research were strictly determined by a general communist party strategy of social development. Moreover, one of the fundamental intentions of the soviet totalitarian science and philosophy was to destroy a national authenticity and cultural distinction of a USSR members and its research in Humanities. Consequently, History of philosophy was not an exception. Recently mentioned soviet ideological pressure was based on the idea of an absolute scientific value of Marxist-Leninist methodology and worldview. Only Marxist-Leninist-based history of philosophy hailed as a true scientific. All other, non-Marxist versions of historical inquires in the field of philosophy were denied and sometimes forbidden because of an "ideological hazard", they were able to deliver. All non-communistic philosophical "misinterpretations" were carefully controlled by special comities related to USSR KGB (Committee for State Security of USSR).

The general approach of soviet history of philosophy (propounded by Vladimir Lenin and which all scientists were persuaded to accept) consisted in division of all philosophical heritages into two main groups:

a) Sources and elements of Marxism;

b) "Opposite force", which had to be criticized on Marxism-Leninism positions.

There are several branches of philosophy which were considered as the sources and elements of Marxism. First of all, it is necessary to mention "Democritus line" (in terms of Vladimir Lenin) — systems of philosophy in history of philosophy which were based on materialistic worldview. Other important sources are British political economy (Adam Smith, David Ricardo, and so forth) and French Utopian Socialism (Henri de Saint-Simon, Charles Fourier and so forth). Otherwise, the main methodological and theoretical basis of Marxism, on Vladimir Lenin's opinion [Lenin, 1977], is German classical idealism in addition with philosophical works of Ludwig Feuerbach (in terms of Friedrich Engels - "German classical philosophy" That's why it was one of the main subjects of research and interpretation of soviet history of philosophy.

The "opposite force" consisted of "Plato line" — idealistic philosophical systems of all the historical epochs, and also of alternative to dialectical materialism methodologies, theories of 
science and epistemologies (Neokantianism, Positivism, Neopositivism, Existentialism and so forth). Both elements of mentioned above distinction were widely and substantially criticized because of its numerous "mistakes", misinterpretations and general false and non-truly-science approach.

There are some significant peculiarities of soviet interpretation of German classical idealism — the philosophical tradition which was methodologically and theoretically conceived by Immanuel Kant.

Due to the mentioned above, one of the main goals of Marxism-Leninism intentions in field of history of German classical philosophy were: a) to discover it deeper; b) find out and highlight its "weak" elements, which were later rejected or corrected by Karl Marx in his philosophical system. Firstly and mostly, research attention of soviet historians of philosophy was focused on Georg Wilhelm Friedrich Hegel's philosophy, but later on, they also began systematic research of Kant's philosophical heritage to compare it with Hegel's and Marx's and to criticize it.

\section{Totalitarian strategies in Kant's philosophy interpretation}

Tradition of research and interpretation of Kant's heritage in Ukrainian philosophy of soviet period took off in 1960's after the main Kant's philosophical texts were translated into Russian. The first published soviet collection of Kant's texts wasn't comprehensive. Some important texts, devoted to the religious problems were not mentioned despite inevitable significance of this topic within Kant's philosophical system. One of the main Kant's questions about the human being "What may I hope" [Kant, 1998] may find its answer in philosophy of religion. Human image cannot be comprehensive without being reflected in mentioned subfield of philosophy. The importance of objective evaluation of social and cultural role of religion phenomenon for contemporary human image is well shown by in recent article by Gennadi Aliaiev [Aliaiev, 2016] which main conclusions author agrees with.

New Ukrainian translations were not provided in this period, likewise the existing translations were ignored, denied and forbidden to use in scientific discourse. One significant peculiarity of soviet history of philosophy is that scientist often used the translations of the main philosophical texts. Original texts written in English, German, French and so forth, were mostly never quoted. In authors personal opinion such peculiarity was the practical implementation of a general intention of soviet totalitarianism to control all possible opinions by putting all the conclusions into the "wright tracks". Some "ideologically correct" interpretations were already hidden present in the translation specially to form the correct opinion in readers mind.

The most known Ukrainian scientists in the field of history of philosophy, who provided their researches on Kant's philosophy in frames of Marxist tradition, were: Pavlo Kopnin, Volodymyr Shynkaruk, Myhailo Bulatov, Anatolii Trubenko, Jurij Kushakov and so forth. This paper touches upon the most significant personalities.

Pavlo Kopnin (1922-1971) was a soviet and Ukrainian philosopher, founder of several philosophical research communities (Tomsk philosophical community, Kyiv philosophical community and so forth), which represented his general and special scientific interests philosophy of science, epistemology, logic, dialectics, history of philosophy. Despite of the fact that he was born and died in Russia, he is acclaimed as one of the most honored personalities of Ukrainian philosophy and history of philosophy. He graduated from Lomonosov State 
University of Moscow (1944), In 1958, after gaining the Doctoral degree (Doctor of philosophical sciences) he moved to Kyiv, where he spent ten years working on different teaching and administrative positions (Head of the philosophy chair in Kyiv Polytechnic Institute, Head of the historical and dialectic materialism chair in Taras Shevchenko state university of Kyiv, Director of the Institute of Philosophy (scientific research institution) of Ukrainian Soviet Socialistic Republic) and publishing his main scientific works: "Dialectics as Logic" (1961), "Hypothesis and reality cognition" (1962), "Idea as the form of reasoning" (1963), "Logical basis of the science" (1968), and so forth. In his books he developed several scientific theories concerning to methodology of science, logic of science and leading role of dialectics in all fields of research. He took part in the discussion of the concept of unity of Logic, Dialectics and Epistemology which was evaluated as crucial and significant.

Pavlo Kopnin researched Immanuel Kant's philosophy mostly from epistemological perspective. He never published a special book devoted to any aspect of Kant's philosophy. Its representation in his books appears as an implementation of discovery of the historical grounds and development of Marxist epistemology. Kant's epistemological approach represented in his "Critic of Pure Reason" and other related texts was valuated as an important condition of later appearance of George Hegel's epistemological positions and formation of his dialectical logic based on the additional method. [Kopnin, 1957] There are several inevitable demerits of such approach: a) due to the described strategy philosophical heritage of Immanuel Kant was discovered inconsistently and partly; b) the conclusions about its weak points were based only on several subjective rational reconstructions made by author; c) Kant's philosophy loses its self-sufficiency and valuated only as contribution to future more relevant theories. In author's opinion, described approach, which refers to Lenin's critical position [Kopnin, 1960], cannot be evaluated as objective and representative in history of philosophy.

Volodymyr Shynkaruk (1928-2001) was a Ukrainian philosopher and historian of philosophy. He graduated from Philosophy department of Taras Shevchenko state university of Kyiv (1950). Since 1951 to 1968 has been working on different positions in University (associated professor, full professor, dean). In 1968 he was admitted on the position of Director of the Institute of Philosophy. Volodymyr Shynkaruk was proficient historian of philosophy, nevertheless he wasn't able (for the political reasons) to do history of philosophy itself. His historical inquiries in the field of philosophy were connected with the Marxist-Leninist dialectical researches he was persuaded to do. However, he published several books which specially touched upon some crucial points of Immanuel Kant's philosophy and some other German classic philosophers. (Epistemology, Logic and Dialectics of I. Kant (1974); Logic, Dialectics and Epistemology of Hegel (1964); Essays on Ludwig Feuerbach's philosophy (1982) and so forth). Some propounded ideas highlighted the necessity of independent evaluation of Kant's ideas, but mostly such intentions were never realized.

The book which gives a good presentation of the general Kant's interpretations tradition is "The Unity of Dialectics, Logic and Epistemology" published in 1977. As was mentioned in the introduction, the book appeared as a result of the synthesis of some previous books concerning to Kant and Hegel. Aim and scope of the book, as also mentioned, were not given by the author himself, but by the Communist party. The aim of the book concerns to the general party task - to research the deep connections between Dialectics and Logic, mentioned in Vladimir Lenin's dairy scribbles. The book contains a detailed historical analysis of a wide range of philosophical traditions and texts, concerned to the dialectics and its unity with logic and epistemology. On the other hand all this work was done for one final reason to criticize and 
valuate all mentioned theories from Marx's positions.

Myhailo Bulatov (born in 1936) is a Ukrainian philosopher and historian of philosophy, disciple of Volodymyr Shinkaruk. He worked on the research positions in the Institute of Philosophy of Ukraine and taught "German classical philosophy" course on philosophical department of Taras Shevchenko National University of Kyiv. His research heritage consists of books and articles published both in soviet and independent times. His past and recent works perfectly describe the distinction between soviet and contemporary approaches in history of philosophy. His book "Lenin's analysis of German classical philosophy: problems of Logic, Dialectics and History of Philosophy" published in 1974 was a good example of the soviet image of Kant's philosophy problems and the frames of its possible analysis.

Jurij Kushakov (1946-2016) was a Ukrainian philosopher and historian of philosophy disciple of Volodymyr Shinkaruk and Valerij Bosenko. After graduation from Philosophy department of Taras Shevchenko state university of Kyiv he worked on teaching positions. Dialectics, Marx's philosophy and German classical philosophy were his research fields. His main researches on Kant's philosophy were done in the same tradition as was described above.

\section{Kant's philosophy in modern Ukraine}

After Ukraine got political independence from the USSR in 1991 the ideological pressure disappeared. Ukrainian philosophers became able to research German idealism without any limitations. During the years of independence a lot of different philosophical research communities appeared. Among them also present communities of Kant's philosophy researchers. Such communities are functioning in different Ukrainian educational and scientific institutions. In Kyiv there are three scientific centers that provide Kant's philosophy researches:

a) Taras Shevchenko national university of Kyiv. (Department History of Philisophy, Department of Theoretical and Practical philosophy);

b) National University of "Kyiv-Mohyla Academy" (Department of philosophy)

c) Hryhorii Skovoroda National Institute of Philosophy National Academy of Science of Ukraine.

Local Kant's philosophy research communities also can be found at all philosophy faculties of the country.

All interested and inspired by Kant's philosophy researchers are now united in "Kant's community of Ukraine" - public organization that was founded in 1998. The mission of this organization consists in increasing of quality of philosophical researches and native intellectual culture development. "Kant's community of Ukraine" is now headed by Professor Mikhail Minakov. “Community' organizes and takes part in numerous specialized conferences all over Ukraine and abroad, provides publication activity.

One of the most important vectors of development for this community is a Ukrainian translation of the most significant texts written originally by Immanuel Kant, and his famous followers. Now day's main theoretical works by Immanuel Kant are translated into Ukrainian. Nevertheless, this translation work is now just started, and there a lot of texts still waiting to be translated. Ukrainian philosophical terminology is also developing now. A lot of terms are now being discussed to reduce an influence of the totalitarian past on non-totalitarian future of Ukrainian Kant's philosophy researches.

Nowadays, methodological approach to the scientific research of Immanuel Kant's philosophy was fundamentally modernized in accordance with the new strategies of the 
history of Ukrainian Philosophy development. Mentioned strategies are widely described in monograph "Modern methodological conceptions of inquiry of History of Ukrainian philosophy" by Sergii Rudenko [Rudenko, 2012]. The mentioned new strategies are focused on overcoming of still remaining impact of soviet scientific and ideological prejudices, which definitely appear as obstacles for objectivity. Some useful practical experience notes about facing such prejudices and possible ways of overcoming in contemporary international research projects were suggested in our recent paper "Management features of international educational projects between the universities of Poland and Ukraine" [Rudenko, Bazaluk, Sapenko, Tytarenko, 2018] The modern needs and purposes of higher philosophical education in Ukraine mentioned in the recent scholarly article "Cosmology in the Philosophical Education of Ukraine: History and Modern Condition” [Rudenko, Sobolievskyi, Tytarenko, 2018].

\section{Conclusions}

Most of Kant's philosophy studies made by soviet Ukrainian historians of philosophy were provided in the general ideological frames, formed by communistic government in Moscow. That was the reason of a huge amount of ideological prejudices that can be found in all mentioned researches: a) for instance it was ideologically incorrect to be a follower of Kant's theories and valuate his philosophical system as self-sufficient; b) it was a strong obligation to criticize him for "idealism", "apriorism", "agnosticism", absence of "proper" and "veritable" dialectic method, "system of categories" and so forth; c) only some, "ideologically correct" and "authorized" Kant's texts were researched and critically analyzed. Some other text's ("Opus postumum" and so forth) were not, sometimes, even mentioned; d) soviet historians of philosophy mostly used translations instead of original texts of the works they analyzed.

Consequently, Ukrainian soviet researches of Kant's philosophy were not actually representative, authentic and independent. This tradition can be evaluated as an attempt of foundation of the general ideology in field of philosophy and education.

\section{[D] References}

Aliaiev, Gennadii. Religious Foundations of Culture (The Controversy Between Simon Frank and Simon Lurie on "Vekhi") Philosophy and Cosmology. Vol 16, 2016: 190-198.

Bulatov, Myhailo. Lenin's analysis of German classical philosophy: problems of Logic, Dialectics and History of Philosophy. Kyiv. 1974.

Kant, Immanuel. Critique of Pure Reason, trans. Paul Guyer and Allen Wood. Cambridge: Cambridge University Press, 1998

Kopnin, Pavlo. Dialectics of the reasoning forms in Hegel's philosophy. The Questions of philosophy. Vol. 4, 1957: 51-42.

Kopnin, Pavlo. Perspectives of the Lenin's method of critics of idealistic conceptions. The Bulletin of Kyiv Univessity. Vol.3, 1960: 15-25.

Philosophical encyclopedic dictionary. Edited by V. I. Shynkaruk. Kyiv: Abrys, 2002.

Rudenko, Sergii. Philosophical views by V.P. Petrov. Kyiv: PARAPAN, 2008.

Rudenko, Sergii. Modern methodological conceptions of inquiry of History of Ukrainian philosophy. Kyiv: Vydavnycho-polihrafichnyy tsentr "Kyyivs'kyy universytet", 2012.

Rudenko, Sergii, Jaroslav Sobolievskyi, and Vadym Tytarenko. Cosmology in the Philosophical Education of Ukraine: History and Modern Condition. Philosophy and Cosmology. Vol. 20, 2018: 128-138. DOI: 10.29202/phil-cosm/20/12 
Lenin,Vladimir. The Three Sources and Three Component Parts of Marxism. Lenin's Collected Works, Progress Publishers, 1977, Moscow, Volume 19: 21-28.

Pavel Valilievich Kopnin [edited by Myroslav Popovych]. Moscow, 2010.

Shynkaruk, Volodymyr. Logic, Dialectics and Epistemology of Hegel. Kyiv, 1964.

Shynkaruk, Volodymyr. Epistemology, Logic and Dialectics of I. Kant. Kyiv, 1974.

Shynkaruk, Volodymyr. The Unity of Dialectics, Logic and Epistemology. Kyiv, 1977. 